\title{
Study of Financing Methods in International Trading Company in Iran (Case Study: Mahan Air Company)
}

\author{
Asadollah Mehr Ara', Sedigheh Tootian Esfahani' ${ }^{2}$, Seyed Mohammad Seyedhasani ${ }^{3}$ \\ ${ }^{1}$ Department of Administrative Management, Faculty of Humanities, Qaem Shahr Branch, \\ Islamic Azad University, Qaem Shahr, Iran \\ ${ }^{2}$ Department of Accounting, Faculty of Humanities, Tehran East Branch, Islamic Azad University, Tehran, Iran \\ ${ }^{3}$ Faculty of Management, Tehran University, Tehran, Iran \\ Email: tootian.seda@gmail.com
}

Received 17 December 2015; accepted 12 March 2016; published 15 March 2016

Copyright (C) 2016 by authors and Scientific Research Publishing Inc.

This work is licensed under the Creative Commons Attribution International License (CC BY). http://creativecommons.org/licenses/by/4.0/

(c) () Open Access

\begin{abstract}
In many projects, especially airlines projects type of financing is very important for some reason such as the amount of capital required and sensitivity of project in terms of political, economic and security issues. In this research, researcher with regard to the importance of the issue is to seek to achieve a goal that will be on the way of finding suitable methods for Mahan Air to financing and what is involved the researcher's mind is to introduce and identify best methods of financing from internal and external methods for international trading companies and especially Mahan air. At the first, a survey was conducted from 15 experts to prioritize important ways using pairwise comparisons questionnaires and fuzzy analytical hierarchy process. Then to practical test of obtained priority another questionnaire was used. In order to ensure the validity of the questionnaire professors and experts were asked to comment and their view was confirmed the validity of questionnaire. To ensure unambiguity in the questions and reliability, questionnaire tentatively distributed among 30 individuals and Cronbach's alpha 722/0 was obtained that represented good credit of questionnaire. The results showed that in the financing of projects in the international trading companies in internal resources: loan, equity participation, instalment sale, leasing, internal line of financing, profit sharing respectively and external sources of finance, usance, external line of financing, build, operate and transfer (BOT) and joint venture respectively involved and closer inspection revealed that there was a significant relationship between various methods of financing and success of the project.
\end{abstract}

\section{Keywords}

Financing, Finance, Usance, Build, Operate and Transfer (BOT), Loan, Leasing, 


\section{Instalment Sale, Profit Sharing, Lines of Financing}

\section{Introduction}

One of the ongoing concerns of business executives, especially those who are not dependent on state resources is to provide sufficient funds to meet current needs, achieve goals and implementation of existing or running projects. Administrators will have to decide how to provide the necessary financial resources according to the enterprise's internal policies, conditions prevailing in the country, enterprise's financial condition, the number and the financial ability of shareholders and some marginal conditions. If shareholders have the necessary financial resources with an infusion of cash or non-cash as capital growth solve the enterprise problems. Thus, in addition to meeting the needs of executives, the firm's balance sheet and financial ratios are stronger and help managers in future decision-making conditions. In many cases, the shareholders do not have the financial resource to capital growth or financial managers and company executives do not see necessity for capital growth and prefer to financing from external sources in the form of loans or loan from a bank or financial institutions which in turn is also influenced by the firm's financial condition. If the firm has received numerous loans and don't have sufficient assets for bail out new loans that the firm is get in trouble. Sometimes the financial needs of a firm are the extent that the facilities and loans of domestic banks and financial institutions that are paid according to the firm's financial strength do not scramble their needs. In this case, the form of a consortium more than a bank or financial institution in agreement with each other (Alliance Group) is paid facilities that it is also affected by conditions of financial and banking system. This in the country that does not have powerful and integrated system and infractions such as embezzlement or money laundering occurred too much their money is less visible.

Sometimes due to the condition and nature of financial need, managers need to take loans from foreign banks, and it is also influenced by the political situation prevailing in the interior space and the relations between the countries and between the countries and international institutions. Sometimes managers have used multiple loan methods such as issuance of securities in order to attract capital of people who prefer participating in reliable investments instead of saving cash or transferring them to unknown people and markets. Sometimes managers may turn to companies and institutions that provide them in the form of financial leasing (loan, rent and leasing). Some managers in interaction with organizations or government agencies in operating long-term and extensive projects use financing methods such BOO or BOT. An important aspect of the financial economy is financing process. There are different methods and tools for financing, that each one has its own characteristics and properties. These tools and methods are used depending on the needs, financial strength, conditions of economic enterprises and the diversity of people's behavior in investing and the face of danger. Choosing appropriate method of financing the project is an important issue. In many projects, especially projects in airports type of financing is very important because of issues such as the high amount of capital required, the sensitivity of the project in terms of political, economic and security issues.

In this research, researcher with regard to the importance of the issue is to seek to achieve a goal that would be on the way of finding suitable methods for Mahan Air to financing. Companies have several strategic choices in managing their financing needs some businesses decide to have sufficient cash flow to meet their daily needs, while others have overdraft and loan facilities and some of them use other form of financing of asset (Bender \& Ward, 1956: p. 351).

The most important long-term source of companies including common shares, bond, preferred stock, accumulated earning and long-term bank loans. Short-term source of financing can include short-term bank loanscommercial paper-sale of accounts receivable and inventory putting collateral. Immediate short-term financing refers to funds resources which obtained in the normal course of business. The main sources of urgent financing include commercial credit (creditors) and deferred accounts (Ahmadpour \& Yahyazadehfar, 2011: p. 473).

The first factor that is considered in dividend policy is accumulated earnings, because saving profits are considered as a source of financing. If the accumulated earnings are considered as a source of financing, then companies have retained a lot of profit as accumulated earnings and a small amount of profit dividend among shareholders (Neveu, 1989: p. 417). Commercial credit means normal transactions, in many industries is simple and informal. Institution that unqualified to receive credit from a financial institution may take credit from her seller (Weston \& Brigham, 1975: p. 274). 


\section{Methods of Financing Projects}

In many projects financing have been considered by government officials for some reason such as the high volume of investment required, the high sensitivity of project in terms of political, economic and security issues, reluctance of foreigners and their investment in the fund. Some projects supported by government funds, but in the most important infrastructure projects that is not provided full funding by the government such as oil, gas, petrochemical projects and many other industries to improve the infrastructure need to use foreign investor and use of foreign banks and institutions services. The important thing about choosing any of these methods is conditions and the characteristics of the project and the host country and is to gain best expected efficiency of project. A method was selected that with least amount of time and cost, had cover risks of project. Given policies in the host country is very important to use each of these methods. All methods of financing projects are as follows:

1. Project finance: In this type of financing country or lending institution does not set any conditions for the use of loans and the financing phase is completely isolated from the implementation phase.

2. Finance: Finance literally means "tax" or financing and in the subject of investment it refer to financing by use of internal resources or receive and use foreign loans.

3. Usance: Usance means "respite", "timeout" and "promise to pay" and in terms of investment it means agreement on payments of received technology or equipment in return of bill after date.

4. Build, operate, and transfer (BOT): Foreign investor after taking unit concession will transfer responsibility of financing, construction and operation of industrial units to the host country for a specified period.

5. Loans: This type of facilities is used for projects with significant social and economic impacts that have long execution time and it may also are not profitable.

6. Leasing: This is a mid-term credit which capital equipment and other fixed assets such as plant, machinery and equipment for industry are provided based on it.

7. Instalment sale: In instalment sale the ownership of capital is transferred at the time of delivery to the beneficiary and the bank buys equipment and machinery and sells to the beneficiary by applying percentage of benefit.

8. Profit sharing: Two or more partners providing capital to finance a firm. Participants in proportion to their share are share in gain or loss of the company.

9. Line of financing: According to this method, banks finance SMEs of member's country (generally in the private sector) through loans, leasing and instalment sale to help the growth and development of SMEs.

\subsection{Research Methodology}

This research was applied research and tried to develop a way to solve real and practical problems based on the theories, laws, etc. Based on the nature and control of variables this research is non-experimental and descriptive study that carried out as survey. This research is a field research, but documentation and basic information to build a model extracted from library resources. The aim of study was to investigate various methods of financing in international trade company and to explain the relationship between the various methods of financing and the success of international businesses. The research was done in Mahan Air Company in the period of 20122013. Each model is starting point to conduct research and studies so that determines variables and the relationships between them (Edwards et al, 2000). The conceptual model is as follows (Figure 1).

To test the above model, regression model as a conceptual and analytical model considering the variables of the study is as follows:

$$
y=\alpha+\beta_{1} x_{1}+\beta_{2} x_{2}+\ldots+\beta_{11} x_{11}+\varepsilon_{1}
$$

Intercept $\beta_{1}, \ldots \beta_{11}$ : Estimator the slope of regression: $\alpha$. The success of the project: $y . x_{11}$ to $x_{1}$ include: loan, leasing, instalment sale, equity participation, profit sharing, internal line of financing, finance, usance, external line of financing, (BOT), joint venture.

Statistical society and sampling

In this study, to identify important ways of financing from advisors and financial experts and investment managers in Mahan, those selected who has three basic requirements:

1. Minimum 10 years experience in financial and economic areas.

2. Have at least a bachelor's degree in financial and economic areas. 


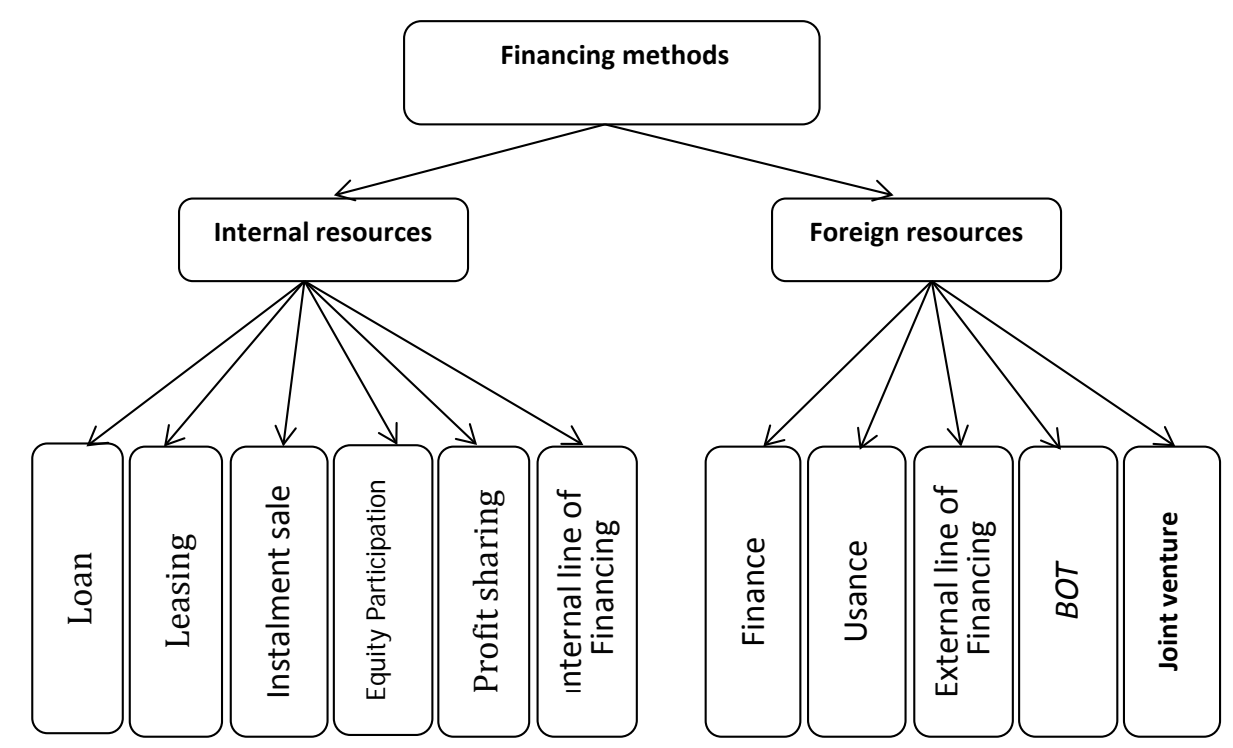

Figure 1. Conceptual model.

3. Having a major role in economic and financial areas, especially financial decisions.

Given the above conditions 15 persons were selected that express their opinion in the phase of setting priorities of financing methods, based on a group decision-making process. In the next stage in order to practical testing priorities and specified financing methods according to the experts' opinion, a poll was conducted so that compare the results with the facts.

According to the definition of statistical society, it can be considered all real or supposed members who are interested to be generalized in research findings (Delavar, 1995: p. 112) or all of the real or hypothetical person, a group of people, events and objects that researchers applies its findings to them (Salimi, 1998: p. 41). The population in this study was experts and financial managers of Mahan air. However, since it was virtually impossible to collect data from all of the population a sample was selected from the population. The sampling method was convenience sampling.

\subsection{Sample Size}

In this study, all experts and financial managers in Mahan air considered as sample that are about 163 persons. Questionnaires were distributed to the sample size and finally, the 115 returned questionnaires were tested to further analysis. Preliminary data was gathered by researcher in forms of first-hand observations, questionnaires and interviews. Secondary data are obtained from the study and referred to the documents and reports from research in the time period of study and for collecting the field data questionnaire have been used. Questionnaire was arranged based on ordinal scale and five-point Likert scale order including 5 scales: very high, high, medium, low, very low.

\subsection{Validity and Reliability}

The validity comes from the term of "valid" means right and correct and validity meaning is to be correct and right. Validity means that a measuring tool, able to measure the desired characteristics and properties (Khaki, 2007: p. 288). Validity means that the measuring devices must be able to assess what it is looking for (Khaki, 2003). Validity is categorized in different forms like content validity. Validity ensures us that a scale have sufficient series of cases and examples for the use of the concept. In this study the basis of questionnaire is our standard model, so that to ensure the validity, questionnaire was given to a number of professors and experts that their view was confirmed the validity of the questionnaire. Reliability means that the extent a measurement tool gives the same results in the same conditions (Hafeznia, 1998). According to the type of questions and items used in the study of topics of interest, in order to determine the reliability of questionnaire the method of calculating Cronbach’s alpha coefficient (the formula) was used. 


$$
\text { Alfa }=(n / n-1)\left(\frac{s t^{2} \sum_{i}^{n} s i^{2}}{s t^{2}}\right)
$$

The second phase questionnaire was distributed among 30 individuals for testing. In this study, Cronbach's alpha coefficient was used to assess the validity of the questionnaire. The Cronbach's alpha obtained 722/0, which indicates that the questionnaire is in good standing.

In paired comparisons matrix obtained from expert's comments in the hierarchy of analysis, compatibility rate should be provided, that reflects the internal consistency of comments. Consistency rate is a mechanism that determines the compatibility of comparisons. This mechanism shows how much we can trusted to the priorities of group members or priorities of combined tables. Sometimes it is possible that the comparison made by the decision-maker does not fit in this cases inconsistency was occurred in comparisons. If Consistency rate is less than $10 \%$, comparisons consistency can be accepted. Given the amount of internal financing matrix $03 / 0$ and $06 / 0$ for external financing matrix which is less than $01 / 0$ it can be said that there are good consistency rate (reliability) in these two matrices.

\subsection{Data Analysis}

In this study, data from each of the questionnaires in descriptive tables using SPSS and Excel based on frequency and relative frequency with comparative charts was analyzed and characterized by importance with respect linguistic variables of that numbers from 1 to 9 was allocated and the matrix of pairwise comparisons has been completed two by two and formed the importance of each factor on the importance of other factors for each numerical. At this point the rate and consistency, at this point the consistency rate and, Cronbach's alpha was calculated. Based on the analysis they need three-valued table in fuzzy pairwise comparisons were through the three-valued table or triangular fuzzy 3 - 3 table, the matrix numbers was fuzzy then by determining the geometric mean of group comments central limit (m) and upper limit (U) and lower limit (L) was found. The basis of data analysis is use of fuzzy and hierarchy analysis method or namely FAHP. The regression model is used to investigate the relationship between the components of model. Regression analysis is a technique for modeling and analyzing numerical data. Data values for the independent variable (in this case-financing methods variables including domestic and foreign investment, including loans, leasing, installment sale, equity participation, profit sharing, internal line of financing,, finance, usance, foreign line of financing, BOT (build, operate, transfer) and joint venture) and one or more variables is independent dependent variable (in this study dependent variable are project success).

\section{Research Findings}

In determining the appropriate methods of internal financing, equity participation with 20/0 value is the most important and profit sharing with 15/0 value is least important among the factors and importance of installment sale with 19/0 value and leasing with 18/0 value and internal line of financing with 17/0 value and loans with $14 / 0$ value have 2 nd to 5 th priorities. The consistency rate calculated by Expertise Choice is $03 / 0$ and is less than $10 / 0$, so it can be said that there is a good consistency between comparisons. And in determining the appropriate method of external financing, the finance with $29 / 0$ value is the most important and joint venture with $08 / 0$ value is the least important among the factors and the importance of usance with 25/0 value in the second priority, external line of financing and build, operation, transfer (BOT) methods with 19/0 value, is also in the third priority of external financing. Consistency rate calculated by Expertise Choice is $06 / 0$ and is less than $10 / 0$, so that we can say that there is good consistency among comparisons. In the regression model $x_{11}$ to $x_{1}$ include: loan, leasing, instalment sale, equity participation, profit sharing, internal line of financing, finance, usance, external line of financing, (BOT), joint venture and project success (dependent variable) showed by $y$ and as it can be seen that it is a regression coefficient and is $\beta_{1}=305 / 0$ to $\beta_{11}=344 / 0$ and means that for one unit change in the independent variable, the success of project up $0 / 335$ to $0 / 334$ unit increases and because of $t=002 / 3$ to $t=778 / 3$ as a result regression coefficient is significant and hypothesis is accepted at the confidence level of $95 \%$ (There is significant relationship between methods of financing and project success in the financing of projects in the international trading companies) (hypothesis accepted). 
1) There are different ways of financing in international trading companies.

2) There are different methods of internal and external financing in international trading companies.

3) Equity participation is the most important way among the different internal ways of financing in international trading companies.

4) Finance is the most important way among the different external ways of financing in international trading companies.

5) Profit sharing is the least important way among the different internal ways of financing in international trading companies.

6) Joint venture is the least important way among the different external ways of financing in international trading companies.

7) Different methods of internal financing in international trading companies in order of importance are:
1. Loans
2. Equity participation
3. Instalment sale
4. Leasing
5. Internal line of Financing
6. Profit sharing

8) Different methods of external financing in international trading companies in order of importance are:

1. Finance

2. Usance

3. External line of Financing

4. Build, operation, transfer (BOT)

5. Joint venture

9) The results of the statistical analysis suggest that this hypothesis is supported. Therefore it can be said that choosing loans method is directly related to the success of the project at $95 \%$ level of confidence and after analyzing the data, at the significant level of 0/95 and error level of 0/05 $\mathrm{T}$ test of this hypothesis (3/002) is in the interval accepted and since standard coefficient is positive and $0 / 305$, we can say that this is a direct effect. It means that a unit change in the variable loans increases the variable success of the project in the amount of $0 / 305$.

10)The results of the statistical analysis indicated that this hypothesis is supported. Therefore it can be said that choosing instalment sale method is directly related to the success of the project at $95 \%$ level of confidence and after analysing the data, at the significant level of 95/0 and error level of 05/0 T test of this hypothesis (3/701) is in the interval accepted and since standard coefficient is positive and $0 / 309$, we can say that this is a direct effect. It means that a unit change in the variable instalment sale, increases the variable success of the project in the amount of $0 / 309$.

11)The results of the statistical analysis suggests that this hypothesis is supported. Therefore it can be said that choosing profit sharing method is directly related to the success of the project at $95 \%$ level of confidence and after analysing the data, at the significant level of 0/95 and error level of 0/05 T test of this hypothesis (3/782) is in the interval accepted and since standard coefficient is positive and $0 / 313$, we can say that this is a direct effect. It means that a unit change in the variable profit sharing, increases the variable success of the project in the amount of $0 / 313$.

12)The results of the statistical analysis indicated that this hypothesis is supported. Therefore it can be said that choosing finance method is directly related to the success of the project at $95 \%$ level of confidence and after analysing the data, at the significant level of 0/95 and error level of 0/05 $\mathrm{T}$ test of this hypothesis (3/702) is in the interval accepted and since standard coefficient is positive and $0 / 335$, we can say that this is a direct effect. It means that a unit change in the variable finance, increases the variable success of the project in the amount of $0 / 335$.

13)The results of the statistical analysis indicated that this hypothesis is supported. Therefore it can be said that choosing joint venture method is directly related to the success of the project at $95 \%$ level of confidence and after analysing the data, at the significant level of 0/95 and error level of 0/05 T test of this hypothesis (3/778) is in the interval accepted and since standard coefficient is positive and 0/344, we can say that this is a direct effect. It means that a unit change in the variable joint venture, increases the variable success of the project in the amount of $0 / 344$. 
14)The results of the statistical analysis indicated that this hypothesis is supported. Therefore it can be said that choosing BOT method is directly related to the success of the project at $95 \%$ level of confidence and after analysing the data, at the significant level of 0/95 and error level of 0/05 $\mathrm{T}$ test of this hypothesis (3/236) is in the interval accepted and since standard coefficient is positive and 0/381, we can say that this is a direct effect. It means that a unit change in the variable BOT, increases the variable success of the project in the amount of $0 / 381$.

15)The results of the statistical analysis indicated that this hypothesis is supported. Therefore it can be said that choosing external line of financing method is directly related to the success of the project at $95 \%$ level of confidence and after analysing the data, at the significant level of 0/95 and error level of 0/05 $\mathrm{T}$ test of this hypothesis (3/703) is in the interval accepted and since standard coefficient is positive and 0/385, we can say that this is a direct effect. It means that a unit change in the variable external line of financing, increases the variable success of the project in the amount of 0/385.

16)The results of the statistical analysis indicated that this hypothesis is supported. Therefore it can be said that choosing equity participation method is directly related to the success of the project at $95 \%$ level of confidence and after analysing the data, at the significant level of 0/95 and error level of 0/05 $\mathrm{T}$ test of this hypothesis $(5 / 528)$ is in the interval accepted and since standard coefficient is positive and $0 / 422$, we can say that this is a direct effect. It means that a unit change in the variable equity participation, increases the variable success of the project in the amount of 0/422.

17)The results of the statistical analysis indicated that this hypothesis is supported. Therefore it can be said that choosing usance method is directly related to the success of the project at $95 \%$ level of confidence and after analysing the data, at the significant level of 0/95 and error level of 0/05 T test of this hypothesis (5/548) is in the interval accepted and since standard coefficient is positive and 0/439, we can say that this is a direct effect. It means that a unit change in the variable usance, increases the variable success of the project in the amount of $0 / 439$.

18)The results of the statistical analysis indicated that this hypothesis is supported. Therefore it can be said that choosing internal line of financing method is directly related to the success of the project at $95 \%$ level of confidence and after analysing the data, at the significant level of 0/95 and error level of 0/05 $\mathrm{T}$ test of this hypothesis (5/521) is in the interval accepted and since standard coefficient is positive and 0/443, we can say that this is a direct effect. It means that a unit change in the variable internal line of financing increases the variable success of the project in the amount of 0/443.

19)The results of the statistical analysis indicated that this hypothesis is supported. Therefore it can be said that choosing leasing method is directly related to the success of the project at $95 \%$ level of confidence and after analysing the data, at the significant level of 0/95 and error level of 0/05 $\mathrm{T}$ test of this hypothesis (5/58) is in the interval accepted and since standard coefficient is positive and $0 / 489$, we can say that this is a direct effect. It means that a unit change in the variable leasing increases the variable success of the project in the amount of 0/489. Recommendations resulting from the study are listed below:

1. There is significant relationship between choosing the method of financing and project success in the financing of projects in the international trading companies. So choosing the right method can lead to the success of the project. In many projects, especially operational projects type of financing is very important due to some issues such as the amount of capital required, the sensitivity of the project in terms of politic, economic and security.

2. In the financing of projects in the international trading companies through external sources usance is the most important method. So choosing usance method could lead to the success of the project. In finance method we only discuss financing in terms of loans, while in the usance, goods, services or know-how are also imported, in fact these technologies purchased from countries or foreign institutions. Although usance method is costly but due to the transfer of know-how could lead to success.

3. In financing projects in the international trading companies through external sources after usance and finance methods, foreign line of financing, build, operate and transfer(BOT) and finally joint venture is proposed that due to security issues and the lack of good faith and the sanctions are at the next priorities. For example, in BOT, a foreign investor after obtaining concessions of industrial units, is responsible for the financing, construction and operation of industrial units for a specified period (about 10 to 30 years) and after the ending of the contract, ownership will transfer to the host country. Because of high sensitivity in terms of political, economic and security issues and according to the results of study, this type of contract cannot be successful. How- 
ever, given that the BOT is one of the conventional methods for private sector participation in infrastructure projects in the world, we can take advantage of this type of financing by exerting some changes.

4. Loans are the most important means in the financing of projects in the international trading companies through internal resources, in practical tests a unit change in the variable loans, the lead to 0/305 increase in variable success of the project. So that choosing loan method can lead to the success of the project. In loans we discuss about financing in terms of loans through banks and credit and monetary and financial institutions, it can be proposed in terms of equity participation, instalment sales, leasing and opening of internal lines of credit. In practice the greatest impact is shown by leasing in test of model.

\section{References}

Ahmadpour, A., \& Yahyazadefar, M. (2011). Financial Management. Vol. 1, Mazandaran: Mazandaran University. Bender, R., \& Ward, K. (1956). Corporate Financial Strategy.

Delavar, A. (1995). Statistical Methods in Phycology and Social Sciences. Payam-e-Noor pub, Tehran.

Edwards, J. E., Thomas, M. D., Rosenfeld, P., \& Booth-Kewley, S. (2000). How to Conduct Organizational Surveys: A Step-by-Step Guide. New York: SAGE Publications.

Hafeznia, M. (1998). Introduction to Research Methodology in Humanities. Tehran: SAMT Publication.

Khaki, G. (2003). Style Sheet of Proposal Compilation and Research Critique. Tehran: Baztab Publication.

Khaki, G. (2007). Research Methodology with Approach to Dissertation. Tehran: Baztab Publication.

Neveu, R. P. (1989). Fundamentals of Managerial Finance. New York: South-Western Publishing Company.

Salimi, G. (1998). Introduction to: Research Methodology in Education. Isfahan: Sepahan Publication.

Weston, J. F., \& Brigham, E. F. (1975). Managerial Finance. 5th Edition, London: The Dryden Press. 